\title{
Flush after unilateral adrenalectomy
}

\author{
Florica SANDRU ${ }^{1,2}$, Mihai Cristian DUMITRASCU ${ }^{1,3}$, Ana VALEA ${ }^{4,5}$, Simona Elena ALBU ${ }^{1,3}$, \\ Anda DUMITRASCU ${ }^{6}$, Mara CARSOTE ${ }^{1,6}$ \\ 1"Carol Davila" University of Medicine and Pharmacy, Bucharest, Romania \\ ${ }^{2}$ Elias Emergency University Hospital, Bucharest, Romania \\ ${ }^{3}$ Emergency University Hospital, Bucharest, Romania \\ ${ }^{4}$ Clinical County Hospital, Cluj-Napoca, Romania \\ 5"Iuliu Hatieganu" University of Medicine and Pharmacy, Cluj-Napoca, Romania \\ 6"C.I. Parhon" National Institute of Endocrinology, Bucharest, Romania
}

\begin{abstract}
MEN (multiple endocrine neoplasia) type $2 A$ syndrome, a rare autosomal dominant condition of RET proto-oncogene gain-of-function mutations mostly involves medullar thyroid cancer and pheocromocytoma $(40-50 \%)$ while primary hyperparathyroidism has a less frequent incidence (based on genotype-phenotype correlations). We introduce a female case of MEN $2 A$ syndrome with a particular evolution. This is a case report. A 38-old year female with family history of MEN2A syndrome, is currently experiencing transitory flush associated with mild palpitations (maximum 135/80 mmHg, respective 100-100 beats/minute). 6 years ago she had total thyroidectomy for medullar thyroid cancer (normal plasma metanephrines/normetanephrines and adrenal aspects at computed tomography). 2 years later she was detected with a unilateral pheocromocytoma. Laparoscopic left adrenalectomy was done. Currently, only an increase of plasma metanephrines is postive (twice normal upper limits), not plasma normetanephrines, nor urinary 24-hour metanephrines and normetanephrines. Computed tomography showed a right adrenal tumor of $1.3 / 2.3 \mathrm{~cm}$ and a left adrenal tumor of $1.12 / 0.76 \mathrm{~cm}$. Whole body MIBG (meta-iodo-benzyl guanidine) scintigram was done and confirmed bilateral activity. Bilateral adrenalectomy is necessary. Flush after partial adrenalectomy in patient with prior thyroidectomy for MEN2A syndrome - associated medullar thyroid cancer underlines pheocromocytoma. The newly detected bilateral adrenal masses require an adequate differential diagnosis of post-operatory aspect thus the usefulness of MIBG scintigram.
\end{abstract}

Keywords: flush, pheocromocytoma, adrenalectomy

\section{Abbreviations}

i.v. $=$ intravenous

MEN = multiple endocrine neoplasia

MIBG = meta-iodo-benzyl guanidine

\section{INTRODUCTION}

MEN (multiple endocrine neoplasia) type 2A syndrome, a rare autosomal dominant condition of RET proto-oncogene gain-of-function mutations
$\mathrm{PTH}=$ parathormone

$\mathrm{TSH}=$ thyroid stimulating hormone (variable penetrance, chromosome 10), involves thyroid cancer of medullar type and pheocromocytoma (40-50\% of cases) and primary hyperparathyroidism with a less frequent incidence (based on genotype-phenotype correlations) (1). Specific 
endocrine panel of assays is required in addition to imaging techniques including computed tomography or functional imaging for enterochromafine tissue (2). Surgical approach is the rule, the timing of surgery depends on tumours timing; the general principle is that pheocromocytoma, once confirmed, is priory approached to thyroid removal because of severe risk involving acute adrenaline and noradrenaline release during surgery (3). One time laparoscopic bilateral approach represents the maximum efficacy of surgical approach for bilateral pheocromocytoma as seen also in other conditions like Cushing's disease $(3,4)$.

Medullar thyroid cancer detection may be the first step of syndrome recognition in subjects who are not known with the mutation due to high prevalence in general population of thyroid nodules (5). Thyroid nodules may underline two lines of primary thyroid cancers: those associated with follicular cells and the others involving calcitonin excessive production $(5,6,7)$. The strong gene-based association is described by C-cells-related malignancy and less for papillary/follicular cancers regarding the co-presence of other neoplasia $(6,7,8)$.

\section{AIM}

We introduce a female case of MEN 2A syndrome with a particular evolution.

\section{METHOD}

This is a case report.

\section{CASE DATA}

\section{Current presentation}

This is a 38-old year old non-smoking female coming from endemic area with a medical history of MEN2A syndrome affecting a few members of her family. She has a history of two surgeries and she was referred for a second opinion because she currently experience transitory short episodes of generalized flush associated with mild palpitations without trigger. She has normal menses and she had two births. Clinical evaluation reveals normal blood pressure $(110 / 70 \mathrm{mmHg})$ and heart rhythm (around 70 beats/minute) between crisis. During the episodes of flush she has maximum 135/80 $\mathrm{mmHg}$, respective 100-100 beats/minute. The frequency of flush is highly variable and apparently there is no trigger, neither a medication is required.

\section{Personal medical history}

The subject has the following medical history: 6 years ago she had total thyroidectomy done for medullar thyroid cancer. At that point, the post-operative calcitonin normalized and she was offered daily substitution with levothyroxine (normal TSH was found at periodic assessments). At the moment of surgery she had normal blood pressure and heart beats as well as plasma metanephrines/normetanephrines and adrenal aspects at computed tomography. Two years later she was detected with a unilateral tumor which was considered a pheocromocytoma (a mild increase of plasma metanephrines and normal clinical presentation). Laparoscopic left adrenalectomy was done without complications and the patient was no longer checked up for 4 years when she started to experience the mentioned flushes and she was referred for a second opinion regarding the adequate approach.

\section{Hormonal assays}

On current admission, the subject has normal blood biochemistry panel. The mineral metabolism evaluation shows total calcium of $9.4 \mathrm{mg} /$ $\mathrm{dL}$ (normal levels are between 8.5 and $10.2 \mathrm{mg}$ / $\mathrm{dl}$ ), ionic calculated calcium of $3.84 \mathrm{mg} / \mathrm{dL}$ (normal ranges are between 3.9 and $4.9 \mathrm{mg} / \mathrm{dl}$ ), total proteins $8 \mathrm{~g} / \mathrm{dl}$ (normal values: 6.5-8.7 g/dl), phosphorus of $3.6 \mathrm{mg} / \mathrm{dl}$ (normal limits: $2.5-4.5 \mathrm{mg} /$ $\mathrm{dl}$ ), alkaline phosphatase of $57 \mathrm{U} / \mathrm{l}$ (normal: 38$105 \mathrm{U} / \mathrm{l}$ ), 25-hydroxyvitamin D of $50 \mathrm{ng} / \mathrm{ml}$ (normal values $>30 \mathrm{ng} / \mathrm{ml}$ ), parathormone (PTH) of 30 $\mathrm{pg} / \mathrm{ml}$ (normal ranges between 15 and $65 \mathrm{pg} / \mathrm{ml}$ ).

Thyroid assays show correct levothyroxine substitution based on a TSH (thyoid stimulating hormone) of $1 \mu \mathrm{Ul} / \mathrm{ml}$ (normal 0.5-4.5 $\mu \mathrm{Ul} / \mathrm{ml}$ under $125 \mu \mathrm{g}$ of levothyroxine per day). Calcitonin is of $2.6 \mathrm{pg} / \mathrm{ml}$ (normal values are between 1 and 4.8 $\mathrm{mg} / \mathrm{dl}$ ). Plasma metanephrines are $144 \mathrm{pg} / \mathrm{ml}$, repeated $148 \mathrm{pg} / \mathrm{ml}$ (normal: $10-90 \mathrm{pg} / \mathrm{ml}$ ), and plasma normetanephrines of $58 \mathrm{pg} / \mathrm{ml}$, repeated $78 \mathrm{pg} / \mathrm{ml}$ (normal: $20-200 \mathrm{pg} / \mathrm{ml}$ ). Similar assays were done around flush episodes with the same values.Urinary 24-hour metanephrines are 292 $\mu \mathrm{g} / 24-\mathrm{h}$, repeated $313 \mu \mathrm{g} / 24-\mathrm{h}$ (normal: 50-350 $\mu \mathrm{g} / 24-\mathrm{h}$ ), urinary $24-\mathrm{h}$ normetanephrines are 256 $\mu \mathrm{g} / 24-\mathrm{h}$, repeated $239 \mu \mathrm{g} / 24-\mathrm{h}$ (normal: 100$600 \mu \mathrm{g} / 24-\mathrm{h})$. Neuroendocrine markers are normal: neuron specific enolase $4 \mathrm{ng} / \mathrm{ml}$ (normal: 0-12 ng/ml), chromogranin A $37 \mathrm{ng} / \mathrm{ml}$ (normal: 20-100 ng/ml), serotonin $143 \mathrm{ng} / \mathrm{ml}$ (normal: $80-400 \mathrm{ng} / \mathrm{ml}$ ). 


\section{Imaging techniques}

I.v. (intravenous) contrast abdominal computed tomography showed a right adrenal tumor of 1.3 by $2.3 \mathrm{~cm}$ (centimeter) (Figure 1). Also, a left adrenal tumor of 1.12 by $0.76 \mathrm{~cm}$ was found at the level of previous surgery (Figure 2). Whole body I23-MIBG (Meta-iodo-benzyl guanidine) scintigram was done and confirmed bilateral activity. Bilateral adrenalectomy is necessary.

\section{DISCUSSION}

The particular aspect of the case is the presence of small left adrenal tumor despite the fact that medical records showed a total adrenalectomy. A relapse is possible but the risk of malignancy is low, most probably the procedure was partially done at that time from the begining. As limits of the case we mention the lack of specific gene mu- tation and insufficient data regarding the medical records prior to current admission. Also, currently the values of plasma and 3-h urinary metanephrines and normetanephrines seem useful for an adequate confirmation of pheocromocytoma. The indication of bilateral approach is needed because the tumor on the left adrenal does not seem a post-operatory aspect, neither an incidentaloma because of the MIBG scintigram results. The risk of developing an adrenal incidentaloma is age-related but in this case functional activity excluded the diagnosis (9).

\section{The adrenalectomy technique}

In cases with partial adrenalectomy, one in every three patients displays primary adrenal insufficiency requiring replacement therapy (3). In this case we had only unilateral procedure so normal adrenal function was identified. If bilateral tumors

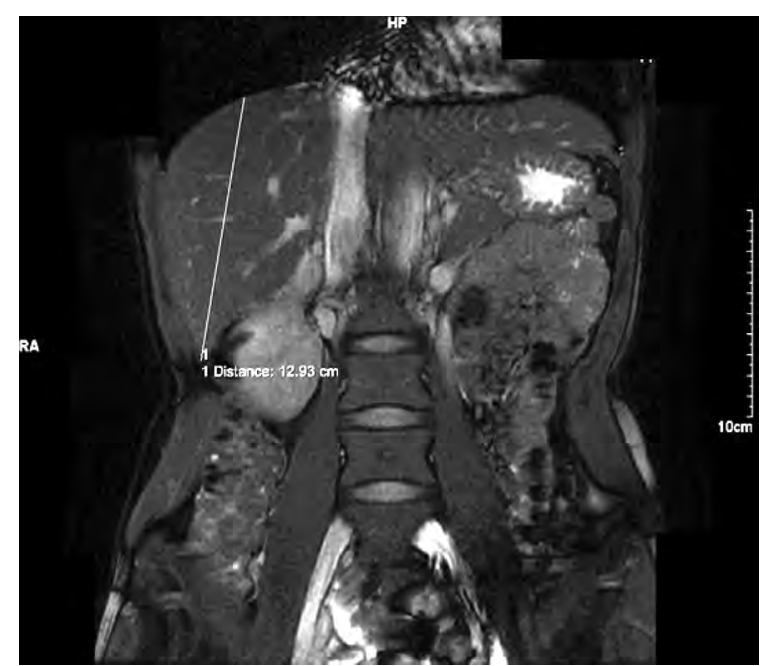

FIGURE 1A. Liver and right adrenal aspect

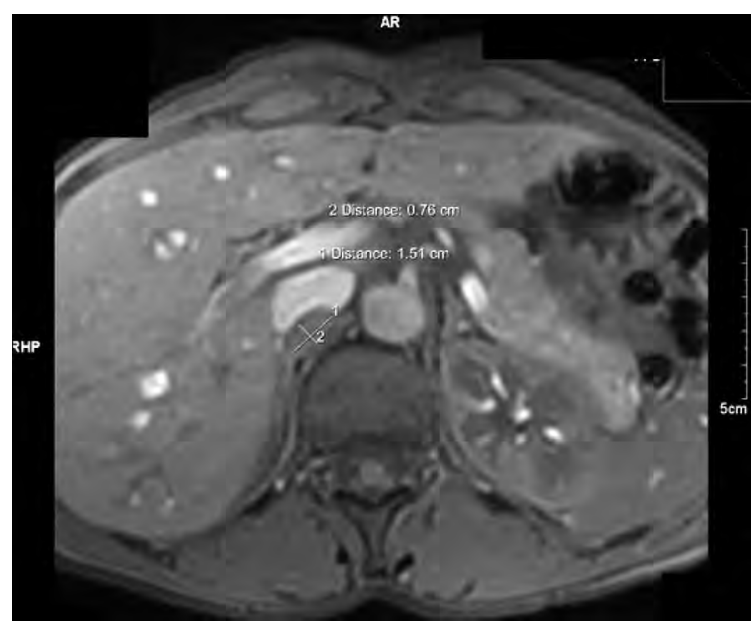

FIGURE 1B. Right adrenal tumor (a pheocromocytoma)

FIGURE 1. i.v. contrast abdominal magnetic resonance imagery showing a right adrenal tumor of 1.3 by $2.3 \mathrm{~cm}$ on a young female with MEN2A syndrome
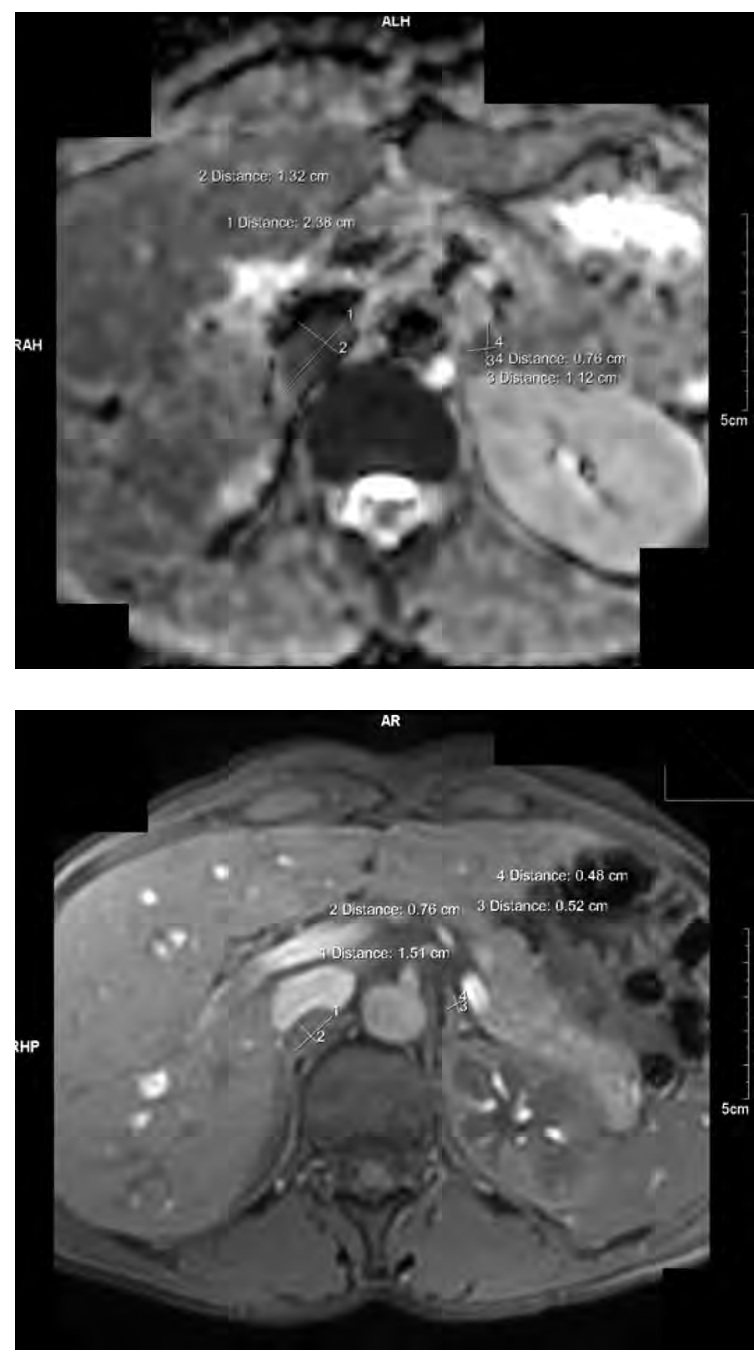

FIGURE 2. A left adrenal tumour of 1.12 by $0.76 \mathrm{~cm}$ was found at the level of previous surgery (bilateral pheocromocytoma) - different transversal sections of abdominal magnetic resonance imagery 
are synchronously detected and they have obviously of different sizes, the removal of the lager tumor in addition to partial removal of the one with a smaller mass is advised by some surgeons (3). However, the risk of relapse and additional surgery is high because of the genetic background while partial technique is not a guarantee that adrenal replacement is not necessary (3). Modern days brought a real progress in the field of adrenal surgery which is no longer open but laparoscopic, including in large tumors even with cystic consistence $(3,10)$. In children, the cortex sparing surgery is preferred in many cases where malignancy is not suspected but the typical approach is open in majority of cases $(11,12)$.

\section{MEN syndromes}

This case introduces a MEN2A syndrome which is a part of MEN syndromes. 4 types have been reported combining endocrine and neuroendocrine tumors in addition to skin and bone anomalies $(13,14,15)$. The most aggressive are cancers like medullar thyroid carcinoma, pancreatic neuroendocrine tumors etc. $(16,17)$. In this case the thyroidectomy was promptly done and there was no sign of relapse 6 years later. When it comes to pheocromocytoma a mild phenotype is described, but the indication of both adrenal remove remains even it does not seem an emergency for the moment because of the assays (only plasma metanephrines are increased). The patient neither develops primary hypeparathyroidsim, the third component of MEN2A syndrome bringing complications like kidney stone, osteoporosis and fractures $(18,19,20)$. Prophylactic thyroidectomy is done in children with MEN2A syndrome depending of specific mutation while parathyroidectomy is not (21). The specific codon mutation is classified in three risk categories and this is correlated with the medullar thyroid cancer aggressively and the risk of developing PTH anomalies (22). Skin lesions in MEN2A syndrome (a part from cutaneous manifestations of high blood pressure crisis and pheocromocytoma) involves lichen amyloidosis in some cases (not this one) (23). Nowadays a refine of risk-oriented management of persons with MEN2A syndrome is registered (24).

\section{CONCLUSION}

Flush after partial adrenalectomy in patient with prior thyroidectomy for MEN2A syndrome - associated medullar thyroid cancer underlines pheocromocytoma. The newly detected bilateral adrenal masses require an adequate differential diagnosis of post-operatory aspect thus the usefulness of MIBG scintigram.

Conflict of interest: none declared Financial support: none declared

\section{REFERENCES}

1. Breza J Jr, Breza J Sr. Multiple endocrine neoplasia 2A (MEN 2A) syndrome. Bratisl Lek Listy. 2018;119(2):120-125.

2. Taïeb D, Kebebew E, Castinetti F, Chen CC, Henry JF, Pacak K. Diagnosis and preoperative imaging of multiple endocrine neoplasia type 2: Current status and future directions. Clin Endocrinol (Oxf). 2014; 81(3):317-28.

3. Pedullà $G$, Crocetti D, Paliotta $A$, Tarallo MR, De Gori A, Cavallaro G, De Toma G. Surgical treatment of pheochromocytoma in MEN 2. Ann Ital Chir. 2014;85(5):443-7.

4. Paduraru DN, Nica A, Carsote M, Valea A. Adrenalectomy for Cushing's syndrome: do's and don'ts. Journal of Medicine and Life. 2016;4(9):334-341.

5. Dumitru N, Ghemigian A, Carsote M, Albu SE, Terzea D, Valea A. Thyroid nodules after initial evaluation by primary health care practitioners: An ultrasound pictorial essay. Archives of the Balkan Medical Union. 2016;51(3):434-438.

6. Carsote M, Albu SE, lorgulescu R, Dumitrascu A, Terzea D, Goldstein A, Poiana C. From vasomotor symptoms to solid and insular papillary thyroid cancer with oxyphil variant areas. Journal of Surgical Sciences. 2015;2(2):87-91.

7. Lodish M. Multiple endocrine neoplasia type 2. Front Horm Res. 2013;41:16-29.

8. Poiana C, Virtej I, Carsote M, Banceanu M, Sajin M, Stanescu B, loachim D, Hortopan $D$, Coculescu M. Virilising Sertoli-Leydig cell tumour associated with thyroid papillary carcinoma: case report and general considerations. Gynecol Endocrinol 2010; 26(8):617-622.

9. Gheorghisan-Galateanu AA, Carsote M, Valea A. Incidentaloma: From general practice to specific endocrine frame. J Pak Med Assoc. 2017; 67(6):917-922.

10. Poiana C, Carsote M, Chirita C, Terzea D, Paun S, Beuran M. Giant adrenal cyst: Case study. J Med Life 2010;3(3):308-313.

11. Traynor MD Jr, Sada A, Thompson GB, Moir CR, Bancos I, Farley DR, Dy BM, Lyden ML, Habermann EB, McKenzie TJ. Adrenalectomy for non-neuroblastic pathology in children. Pediatr Surg Int. 2019 Nov 5.
12. Carsote M, Ghemigian A, Terzea D, Gheorghisan-Galateanu AA, Valea A. Cystic adrenal lesions: Focus on pediatric population (a review). Clujul Med. 2017; 90(1):5-12.

13. Poiana C, Carsote M, Ardeleanu C, Terzea D, Avramescu ET, Neamtu MC, Miulescu $R D$. The value of the immunohistochemistry in a case of gastric neuroendocrine tumor and thyroid metastasis. Rom J Morphol Embryol. 2011; 52(1):187-92.

14. Decmann A, Patócs A, Igaz P. Overview of Genetically Determined Diseases/Multiple Endocrine Neoplasia Syndromes Predisposing to Endocrine Tumors. Exp Suppl. 2019;111:105-127.

15. Poiana C, Neamţu MC, Avramescu ET, Carsote M, Trifănescu R, Terzea D, Neamtu OM, Ferechide D, Danciulescu Miulescu R. The poor prognosis factors in G2 neuroendocrine tumor. Rom J Morphol Embryol. 2013; 54(3 Suppl):717-20.

16. Al-Salameh A, Baudry C, Cohen R. Update on multiple endocrine neoplasia Type 1 and 2. Presse Med. 2018 Sep;47(9):722-731. 
17. Poiana C, Neamtu MC, Avramescu ET, Carsote M, Trifanescu R, Terzea D, Neamtu OM, Danciulescu Miulescu R. The dedifferentiation of neuroendocrine tumor metastases: Myth or reality? Rom J Morphol Embryol. 2013; 54(1):201-3.

18. Radu L, Carsote M, GheorghisanGalateanu AA, Preda SA, Calborean V, Stanescu R, Gheorman V, Albulescu DM. Blood Parathyrin and Mineral Metabolism Dynamics. A clinical analyze. Rev.Chim. (Bucharest). 2018;69(10):2754-2758.

19. Cetani F, Saponaro F, Borsari S, Marcocci C. Familial and Hereditary Forms of Primary Hyperparathyroidism. Front Horm Res. 2019;51:40-51.
20. Poiana C, Radoi V, Carsote M, Bilezekian J. New Clues that May Link Osteoporosis to the Circulating Lipid Profile. Bone Research 2013;1(3):260-266.

21. Garcés Visier C, Espinoza Vega M, Guillén Redondo P, Ollero Fresno JC, Souto Romero H, Luis Huertas A, Espinosa Góngora R, Rico Espiñeira C, Bautista FJ Alonso Calderón JL. Prophylactic thyroidectomy in multiple endocrine neoplasia type $2 A$ in children: A single centre experience. J Pediatr Endocrinol Metab. 2019;32(8):889-893.

22. Raue F, Frank-Raue K. Update on Multiple Endocrine Neoplasia Type 2: Focus on Medullary Thyroid Carcinoma. J Endocr Soc. 2018;2(8):933-943.
23. Qi XP, Peng JZ, Yang XW, Cao ZL, Yu XH, Fang XD, Zhang DH, Zhao JQ. The RET C611Y mutation causes MEN 2A and associated cutaneous lichen amyloidosis. Endocr Connect. 2018 Jul 26. pii: EC-18-0220.

24. Machens A, Dralle H. Advances in risk-oriented surgery for multiple endocrine neoplasia type 2. Endocr Relat Cancer. 2018; 25(2):T41-T52. 